\title{
Necessary Restructuring or Globalization Failure? Shifts in Regional Supplier Relations after the Merger of the Former German Hoechst and French Rhône-Poulenc Groups
}

\author{
Harald Bathelt \& Katrin Kappes
}

\begin{abstract}
Version Post-print/accepted manuscript
Citation Bathelt, H., \& Kappes, K. (2009). Necessary restructuring or

(published version) globalization failure? Shifts in regional supplier relations after the merger of the former German Hoechst and French Rhône-Poulenc groups. Geoforum, 40(2), 158-170.

Copyright / License (C) 2011. This manuscript version is made available under the CC-BY-

NC-ND 4.0 license.

http://creativecommons.org/licenses/by-nc-nd/4.0/

Publisher's Statement The version of record [Bathelt, H., \& Kappes, K. (2009). Necessary restructuring or globalization failure? Shifts in regional supplier relations after the merger of the former German Hoechst and French RhônePoulenc groups. Geoforum, 40(2), 158-170.] is available online at: http://www.sciencedirect.com/science/article/pii/S0016718508000444 [doi: 10.1016/j.geoforum.2008.03.004]
\end{abstract}

How to cite TSpace items

Always cite the published version, so the author(s) will receive recognition through services that track citation counts, e.g. Scopus. If you need to cite the page number of the TSpace version (original manuscript or accepted manuscript) because you cannot access the published version, then cite the TSpace version in addition to the published version using the permanent URI (handle) found on the record page. 


\section{Necessary restructuring or globalization failure? Shifts in regional supplier relations after the merger of the former German Hoechst and French Rhône-Poulenc groups}

Harald Bathelt

University of Toronto, Department of Political Science and Department of Geography, Sidney Smith Hall, 100 St. George Street, Toronto ON M5S 3G3, Canada, E-mail: harald.bathelt@utoronto.ca, URL: http://www.harald-bathelt.com

and

Katrin Kappes

University of Marburg, Department of Geography, Deutschhausstraße 10, D-35032 Marburg, Germany, E-mail: katrinkappes@web.de

Paper to be submitted to

GeoForum 


\title{
Necessary restructuring or globalization failure? Shifts in regional supplier relations after the merger of the former German Hoechst and French
}

\section{Rhône-Poulenc groups}

\begin{abstract}
A large part of the work in economic geography and other social sciences surrounding globalization processes has focused on the prospects of economic growth due to the establishment of global production chains and the rise of new clusters of industrial activity. In recent years, much less attention has been paid to former growth industries and regions that have suffered from the negative consequences of internationalization processes. This paper will explore the cases of two chemical regions, i.e. southern Hessen, Germany and Rhône-Alpes, France. Both regions were forced to undergo drastic restructuring since the mid 1990s due to the merger of the chemical groups Hoechst and Rhône-Poulenc into Aventis. The paper argues that it is beneficial to develop a relational perspective of economic action and interaction in order to better understand these regional transformations and restructuring processes and their consequences. Instead of investigating the development of activities, which became the core operations at Aventis, we will focus on other activities that were considered less important and consequently split off. In analyzing the logic of restructuring and the associated changes in regional supplier relations, this paper aims to contribute to a relational understanding of economic globalization and its associated threats to regional development by focusing on agents who are subject to negative restructuring consequences.
\end{abstract}

Keywords. International mergers, regional restructuring, globalization failure, chemical industry, Aventis, relational economic geography

JEL Classifications. F23, G34, L22, L65, R10 


\section{Introduction}

A large part of the work in economic geography and other social sciences surrounding globalization processes has focused on the prospects for economic growth due to international market reach, the establishment of global production chains and the rise of new clusters of industrial activity as a consequence of international direct investments, acquisitions and mergers. While these are important aspects of the changing international division of labor, much less attention has in recent years been paid to those industries and regions that have suffered from the negative consequences of such internationalization processes. This paper will explore the cases of two chemical regions, i.e. southern Hessen around Frankfurt/Main in Germany, and the Rhône-Alpes region around Lyon and Grenoble in France. Due to the merger of the German Hoechst and the French Rhône-Poulenc groups into Aventis, both areas have experienced drastic restructuring since the mid 1990s, in terms of changes in ownership, reorganization of industries, associated closures of plants/firms and shifts in supplier relations. ${ }^{1}$ While industrial organization in the chemical industry appeared relatively stable until the early 1990s, including changes which were limited in terms of their extent and time span, it seems characteristic of the period since then that capitalist economies have entered a new regime of permanent restructuring (Greco 2004a; 2004b).

The goal of this paper is to investigate the effects of globalization processes in the context of industrial restructuring and deindustrialization, and the associated impact on the social division of labor focusing on the changing social relations between suppliers and producers in localized production contexts. The analysis is conducted from an agent perspective, instead of using aggregated data to describe regional effects. The paper analyzes

${ }^{1}$ For studies of ICI and the Teesside economy, see further Beynon et al. (1994), Greco (2004a) and Chapman (2005). 
the logic of restructuring and the threats of "globalization failures"2 from a spatial perspective, as they relate to the Aventis merger in the late 1990s. In particular, the focus is on the analysis of regional supplier-producer linkages and how their nature is affected by industrial concentration processes. Instead of investigating the growth prospects of those operations that became the core of Aventis, as other studies of international mergers have done, we will focus on the operations that were considered less important and consequently split off. We will show, by using the case of Aventis, that international mergers are associated with drastic regional restructuring, not just producing winners but also losers of globalization. Among the latter are former business units that were sold to other companies or, more or less, left alone to survive outside the formerly established integrated corporate environment. They also include employees who lost their jobs, and suppliers whose customer linkages were cut off.

This paper aims to contribute to a relational understanding of economic deindustrialization associated with international mergers, by focusing on those agents who are negatively affected by such processes. It provides a micro-level reasoning of opportunities, constraints and crises in a region by analyzing the conditions under which individual agents (such as workers, managers and policy makers) and collective actors (such as firms) operate. In contrast with much of the work concerning international mergers and restructuring (for an elaborate contribution, see Ruigrok and van Tulder 1995), we will investigate some of the negative consequences of the merger of Hoechst and Rhône-Poulenc on industrial relations and suppliers linkages. This is done in a regional perspective by focusing on those former

\footnotetext{
${ }^{2}$ This term is used as a metaphor to indicate that decisions in internationalization processes are not always necessary or unavoidable. There are many ways in which, for instance, international mergers can be organized and which operations of the merging firms are included or excluded. The notion of "globalization failures" points at the far-reaching problems that can occur related to losses of decision-making competencies, power or jobs within a region. We particularly talk about failures when the corporate decisions are not sensitive to issues of social inclusion and consequences for the regional economy.
} 
divisions of both groups, which were not integrated into the new global operations, as well as their respective supplier networks (Figure 1).

The paper is structured as follows. Section 2 emphasizes the importance of a relational approach in analyzing industrial restructuring processes. The methodology applied in this research is summarized in section 3. Section 4 analyzes the changes which have occurred in the corporate structure and institutional environment of southern Hessen and Rhône-Alpes, and discusses the regional consequences in terms of employment, the social division of labor and public response. In section 5, the paper will investigate how regional suppliers and service providers have restructured their activities to remain in business or find new markets. It will be shown that only some of the suppliers investigated, more so in Germany than in France, were able to successfully overcome the problems of restructuring by drawing on their expertise which they developed in former interactions. Section 6 summarizes the main arguments of the paper and draws some conclusions.

\section{Industrial restructuring, relational proximity and national systems}

Traditional studies of industrial restructuring have typically analyzed the consequences of structural crises at an aggregate level, i.e. as shrinking processes which cause reverse multiplier effects in regions and national states. Although arguing at the level of firms, Myrdal (1957) demonstrated early on how singular events can act as negative triggers and cause cumulative processes of deindustrialization in the respective regions. Notwithstanding empirical studies about the crisis of mass production since the 1970 s, it was due to the work of such people as Bluestone and Harrison (1982), Massey and Meegan (1982) and Massey (1984) that restructuring processes were discussed in the context of shifts in the wider social and spatial divisions of labor. Although these studies went beyond using a simple multiplier analysis of industrial crises and their consequences, other work in economic geography in the context of industrial restructuring was influenced by ideas of optimal decision-making and/or 
characterized by a high degree of spatial and sectoral aggregation. Through this high level of aggregation, the role of agency received little attention in some of these studies.

Clark's work concerning deindustrialization and sunk costs revealed the limitations of applying models of fully rational decision-making to the analysis of structural changes (Clark 1982; 1983). Stimulated by observations of labor market rigidities and massive job losses in the US steel industry around Pittsburgh, Clark (1983) argued that neoclassical models of discrete exchange were not capable of explaining the rigidities of local labor markets. Instead, he suggested a relational view of contracts which included social elements, and did not exclusively focus on economic exchange. This work particularly pointed out the importance of unilateral power (e.g. that of a single party based on laws and regulations) and bilateral power relations (i.e. based on negotiations between two or more parties) in shaping the restructuring processes, with the latter being built upon the former in a contingent manner. Due to the way these influences operated in specific contexts, industrial restructuring was sometimes delayed and started late, in turn causing regional crises, economic downturns and associated social problems. Based on this and other work, Clark and Tracey (2004) recognized that an appropriate understanding of regional restructuring would have to be based on an agent-centered perspective that emphasizes the conditions under which firms act and interact.

\subsection{Relational economic geography and proximities}

In the past decade, the role of agency has been further conceptualized in relational approaches in economic geography (for an overview, see Yeung 2005; Bathelt 2006). These are fundamentally different from former regional-science approaches in economic geography in that they view economic action as social action. Relational approaches do not study regions or other spatial representations; they focus on economic action, and they analyze the role of economic actors in a spatial perspective. Although the point of departure would often be a 
socio-economic problem at the regional level, a relational approach would focus on the role of agents, and their interaction (Bathelt and Glückler 2003). Agents are not viewed as being perfectly free to make optimal decisions; they are embedded in a socio-institutional context from which they cannot easily separate and which impacts their decision-making. A producer of chemicals, for instance, is bound to its suppliers and customers, and needs to coordinate changes in production standards with other firms before implementing them (Granovetter 1985; Grabher 1993). From a historical perspective, this embeddedness translates into pathdependent developments; in the sense that today's decisions are shaped by existing structures and former decisions (Nelson and Winter 1982). ${ }^{3}$ In the context of chemical production, they are, for example, influenced by former choices regarding the processing of by-products, logistics routines and investments into product pipelines. This path-dependency does not imply, of course, that future decisions are pre-determined by past choices. Economic agents can always decide to shift to new or deviate from existing paths. Processes are contingent in that the agents' strategies and actions are fundamentally open-ended (Sayer 1992). Depending on their strategies and goals, agents can, for instance, make different choices regarding innovation processes even if they operate in otherwise similar contexts.

${ }^{3}$ If, of course, existing linkages and relations with suppliers and customers are too close and too exclusive, this can lead to a situation where firms become locked into an inefficient technological trajectory, or shrinking market context, from which they cannot easily escape (Grabher 1993; Martin and Sunley 2006). Such negative lock-in processes can be especially harmful if they develop within a regional economy. In this case, economic decline and high unemployment in an industry can lead to a regional crisis. In the context of the chemical regions discussed in this paper, lock-in is certainly an issue as some suppliers and service providers had developed rigid relationships with few regional customers, involving little interaction or knowledge exchange. As a consequence, these firms became dependent on their major customers, and had difficulties adjusting to unexpected changes in their economic environment (for further discussion, see Bathelt and Kappes 2008). The argument developed in this paper is that suppliers might be able to avoid such lock-in situations if they develop relationships with their customers that are characterized by dynamic relational proximity. 
We argue that it is advantageous to apply this type of approach, building upon the contextuality, path-dependence and contingency of economic action, to better understand regional transformation and restructuring as a consequence of globalization. This provides an institutional view that goes beyond describing economic action in terms of spatial outcomes. It enables a deeper understanding of social and economic processes by analyzing the changing and newly developing institutional configurations that limit and enable economic interaction. While traditional accounts are restrictive in the sense that they assume economic rationality, some structuralist approaches neglect the role of social actors. As Greco (2004b, p. 142) emphasizes, “[i]ndustrial unemployment and restructuring are ... institutionally constructed processes that are geographically situated. They are not simply the outcome of market forces, but rather of historical and spatial expressions of capitalism." Institutional settings become more diverse as different national systems are integrated and institutional barriers bridged through strong corporate/technology ties within global networks. In line with the relational approach discussed here, global commodity/production chain approaches have developed that apply similar ideas (Dicken et al. 2001; Henderson et al. 2002; Sturgeon 2002). ${ }^{4}$ We will discuss this further in the context of abstract proximity concepts.

These concepts are used by the French proximity school to express the need for consistency, congruence and shared visions in economic production (Rallet and Torre 1999). In general, spatial proximity and shared institutional, social and cultural characteristics create conditions that allow firms to engage in economic transactions and develop long-term business relations, especially if they share a common knowledge basis and similar goals

\footnotetext{
${ }^{4}$ Although these approaches are particularly well-suited for the analysis of global shifts as they develop back and forth through value-chain based linkages, we do not follow this line of inquiry in our paper. The reason is that we are primarily interested in shifts that occur in regional economies, especially linkages between chemical producers and their local supply base.
} 
(cognitive proximity) within a particular value chain (Nooteboom 2000; Zeller 2004). In the case of chemical production, spatial proximity makes it easier, for example, to develop longterm production linkages, establish continuous production flows, and regularly adjust routines based on face-to-face contacts. In a global production environment, spatial proximity is often impossible to achieve because key suppliers of basic chemicals and important customers are often located in other countries around the world. This can create problems since the respective firms operate with different standards and use different production routines. Due to institutional and cultural difference (or distance), it might also be difficult to interpret the actions of others and develop trust. When uncertainties regarding the coordination of production and knowledge acquisition are quite high (He 2006), firms may choose to acquire foreign suppliers or customers, or merge with them, rather than trading products between independent agents. Through the development of closer organizational ties, it becomes easier to generate joint institutions, control production standards, and to avoid misunderstandings. This example shows how firms have different options when generating a reliable production environment and social division of labor. In the language of the proximity school, they may be able to substitute one type of proximity for another in order to overcome problems of uncertainty and enable efficient knowledge circulation in the production chain (Torre and Rallet 2005; Boschma 2005; Zeller 2004).

While international mergers and acquisitions can be viewed as processes of bridging multiple distances and establishing a framework for the generation of close inter-firm linkages at an international scale (Ruigrok and van Tulder 1995), the same processes can also create stress at the regional level for existing network relations. This is, for instance, the case when international mergers result in a situation where established regional supplier networks are being thinned out or replaced by international arrangements. From the viewpoint of the suppliers and service providers, it might become easier to adjust to unexpected ruptures and changes in the production environment if they develop close linkages with their customers, 
involving close social interaction, knowledge exchange and complex services. If such relational proximity (Bathelt and Glückler 2003; Atherton 2003; Amin and Cohendet 2004) revolves around systematic innovation and knowledge creation, it may develop into a dynamic capability. This can help reduce the risk of lock-in and become an important source of competitiveness.

From this, we develop the argument in this paper that regional suppliers and service providers may overcome processes of fundamental ruptures and restructuring if they establish close linkages with a set of core producers and customers, and use these relationships to strengthen their learning capabilities and competencies. In other words, we hypothesize that firms can develop specialized competencies and improve their competitiveness through relational proximity with their business partners. We expect that these firms become more robust during periods of fundamental restructuring as they are used to adjusting their production focus flexibly and expanding into new markets (Bathelt and Griebel 2001; 2002).

\subsection{National systems and institutions}

Although we do not intend to analyze the difficulties that arise when firms from different national institutional and cultural contexts merge, national systems cannot be completely neglected in understanding changes in industrial relations and supplier linkages. The national contexts provide a general reference frame, within which economic agents make decisions, and define important institutional conditions for inter-firm interaction. As powerfully stated in approaches to national innovation systems, different patterns of adjustment are likely to take place in different economies. This is due to the fact that the innovation path, institutions and production structure are closely interrelated in a reflexive manner at the level of the national state (Lundvall 1992; Archibugi et al. 1999; Lundvall and Maskell 2000). The national state defines the basic conditions under which economic production, problem solving and exchange occur in that it regulates core aspects of industrial 
relations, training and education, corporate governance and inter-firm relations (Hall and Soskice 2001). These institutional spheres drive economic specialization within a national state. Specialization processes, which differ between these systems, develop further when particular problems and obstacles arise that require specific institutional adjustments. For instance, the German and French economies likely stimulate different action and adjustments at the firm level when faced with processes of international mergers.

In the German national system, long-term supplier networks tend to develop based on stable labor relations and a consensual structure of corporate governance. These relations often revolve around regional development coalitions which include firms, banks, unions, different state levels and parapublic institutions (Katzenstein 1987; Keck 1993; Hall and Soskice 2001). In this decentralized system of relations, an important role of the state is to enable economic interaction and mediate between different groups of actors. Stable intra- and inter-firm relations are conducive to incremental innovation. These stable relations also support the development of specialized competencies through interactive learning within the value chain, as innovation processes involve intensive interactions between producers and users, and actively involve suppliers. Under these conditions, relational proximity may develop, providing a setting for suppliers and service providers that is conducive for competence-building, based on the firms' internal strengths and external networking capabilities.

On the contrary, the national system in France is much more centralized and is based on direct state involvement in the identification of strategic economic core areas (Chesnais 1993). The national state plays a more active role and has become an important driver of industrial restructuring through nationalization processes and/or subsidies for modernization. This system encourages the development of centralized competencies in specific core industries and the growth of large firms, identified as national champions. While this system drives strategically planned innovation processes and strengthens oligopolistic industry structures in 
parts of the economy, broader networks involving small and medium-sized firms with distributed knowledge bases may not be stimulated to the same extent as in Germany. In general, supplier networks can be expected to be more structured and hierarchical, and innovation initiatives to be driven by the final producers. This is supported by an education and vocational training system revolving around the « grandes écoles », which support the creation of an industrial elite and close government-industry linkages rather than generating broad knowledge networks (Chesnais 1993). From this, one could hypothesize that supplier structures in the French system are, to a lesser extent, characterized by interactive learning and the development of problem-solving competencies.

Although we believe that this may help understand some of the differences in the structure of chemical production between Hoechst and Rhône-Poulenc, we do not imply that characteristics of national systems suffice to explain the successes or failures of restructuring processes in the respective supplier sectors. Such deterministic explanations would not be in accordance with a relational understanding of economic action. In fact, as will be shown in the following sections, empirical findings suggest that similar processes, related to the development of supplier competencies and relational proximity, had a positive impact in both national settings Germany and France. Based on the propositions developed above, we will investigate in which way the merger between Hoechst and Rhône-Poulenc has affected regional supplier linkages, and whether differences can be observed between the former core regions of both corporate groups.

\section{Methodology}

The analysis presented in this paper is based on in-depth empirical work surrounding the restructuring processes of the former Hoechst and Rhône-Poulenc groups in southern Hessen and Rhône-Alpes. This work combined quantitative and qualitative research, including explorative research, fax surveys and structured interviews with chemical firms and 
their regional suppliers ${ }^{5}$, as well as interviews with industry experts and regional observers of the chemical industry. Based on an early study concerning industrial restructuring and the social division of labor in the German chemical industry in the mid 1990s (Bathelt 1997), the research presented in this paper began in the year 2000 in southern Hessen. This study was designed as a random sample based on a complete list of all suppliers and service providers of the former Hoechst group which was provided to us. Of 242 regional suppliers randomly selected from this list, $106(43.8 \%)$ participated in a faxed survey that was conducted in August 2000. In this survey, we aimed to identify structural characteristics and the nature of supplier-producer relations in the chemical industry. Our particular focus was on investigating how the Aventis merger had affected supplier relations of the former Hoechst divisions that had been split off during the merger process. This included questions about the type and intensity of interaction, the extent of knowledge transfers and interactive learning, and the structure of purchasing decisions. In addition, information about changes in the percentage of products sold to the former Hoechst divisions was acquired (Bathelt and Griebel 2001; 2002).

As this was a fully standardized survey which did not provide in-depth insights into the nature of the supplier relationships, and the reasons as to why or why not they had changed, we conducted additional qualitative interviews on similar topics in order to better understand the processes behind the quantitative structures. Between January 2001 and May 2006, a total of 30 interviews with chemical firms and their suppliers and an additional 15 interviews with industry experts were conducted in southern Hessen (Kappes 2006).

\footnotetext{
${ }^{5}$ Relevant for this research were not only chemical firms but also other types of suppliers and service providers from different industries, with different technology backgrounds. The suppliers selected, for instance, included machinery and equipment producers, producers of pumps/filters, technical services, maintenance firms and so on.
} 
The empirical work in Rhône-Alpes began in 2004 after the identification of initial patterns in the shifts of supplier relations for the German case. The goal of this research was to conduct interviews with chemical suppliers in a former core region of Rhône-Poulenc. We chose the Lyon and Grenoble areas in Rhône-Alpes as these were originally characterized by a set of chemical production activities, comparable to those in southern Hessen. Through this, we generated similar supplier samples in both regions. ${ }^{6}$ The methodology applied in the Rhône-Alpes region was similar to that in southern Hessen. However, in the Rhône-Alpes region we were not able acquire a complete list of suppliers. Instead, we initially approached the former Rhône-Poulenc branches, and conducted interviews with them about shifts in the supplier-producer relations due to the Aventis merger. Through the course of this process, we acquired lists of suppliers and service providers from several Rhône-Poulenc successors, and combined them into an integrated supplier data base. Although this data base did not have the same depth as the one for southern Hessen, we thought that it was sufficient to conduct a survey of suppliers, asking the firms similar questions as in the German case. As a result, 65 chemical firms, suppliers and experts in the Lyon and Grenoble regions were interviewed between June 2004 and November 2005, they also filled out standardized questionnaires (Kappes and Trucchi 2005a; 2005b; Kappes 2006). The overall response rate in both regions was relatively high, being above $40 \%$.

For our empirical work, we developed a research design that would allow us to test the hypothesis that a supplier's success in restructuring is positively influenced by relational proximity with its core customers. We designed a questionnaire that helped us distinguish

\footnotetext{
${ }^{6}$ Due to the limited number of firms surveyed, it would have been difficult to divide the samples into homogenous sub-samples of suppliers to be analyzed separately. However, we conducted a differentiated analysis for traders, service providers and hardware suppliers that did not show substantial differences in the nature and changes of supplier-producer relations between both regions.
} 
successful from less successful firms, and measured the degree of relational proximity in the relationships with former Hoechst or Rhône-Poulenc divisions. The degree of relational proximity was measured by the frequency and intensity of interaction, the importance of customer-specific vs. standardized products, as well as the extent of after-sales services, additional consultations, joint problem-solving and research in these relations. As an indicator for the success of a supplier, we used the change in the share (percentage) of products sold to the Hoechst and Rhône-Poulenc successors. If this percentage increased, the respective supplier had been able to develop a stronger relationship with these clients despite the new situation after the merger. Hence, the restructuring and adjustment process was viewed to be successful. If the sales share deceased, a supplier was seemingly not able to maintain its former sales position. We interpreted this as an indication of a less successful adjustment. Those firms which indicated that their sales shares had not changed at all were excluded from further analysis, as we were unsure whether this could generally be viewed as a success or not.

After this survey was completed, we contacted a smaller number of firms again to conduct in-depth interviews on the same topic. ${ }^{7}$ These interviews were meant to provide qualitative information about the processes behind shifts which took place in the social division of labor. In some cases, this led to changes in our original interpretation and classification of firms. By and large, however, quantitative and qualitative information corresponded with each other. While this paper focuses primarily on the changes in the supplier relationships, other publications analyze regional implications of this merger in greater depth (Bathelt and Griebel 2001; 2002; Kobiela 2003; Bathelt and Kappes 2008). Before discussing the results of this research further, the structure of chemical production and

\footnotetext{
${ }^{7}$ In the French case, the order was different. Here, the quantitative information was acquired immediately after each qualitative interview.
} 
regional restructuring processes in both regions before and after the Aventis merger will be described in the next section.

\section{Economic geographies of regional restructuring in the chemical industry}

Since the 1980s, changes in the global settings of the chemical industry put increasing pressure on the Hoechst and Rhône-Poulenc groups to rationalize their structure and extend their spatial reach. On the one hand, this was related to stagnation tendencies in some traditional market segments and increased cost competition, due to the presence of new competitors from newly industrialized countries and high labor costs in the former industry cores. On the other hand, globalization processes offered opportunities for access to new markets, and benefits from increasing economies of scale and synergies in production (e.g. Schumann et al. 1994; Bathelt 1997). Due to new production and ICT technologies and new management practices, firms were able to develop extended international production networks. If companies had a widely diversified and costly production program, specialization and rationalization processes, along with increased international mergers and acquisitions, became particularly important. In the cases of Hoechst and Rhône-Poulenc, which had established large conglomerates of chemical production over time, the restructuring processes not only aimed to reduce existing inefficiencies, but also led to a fundamental restructuring of their respective core regions, especially in the mid 1990s.

\subsection{Restructuring of the former Hoechst group in the southern Hessen region}

In the 20th century, Hoechst developed into a diversified conglomerate of chemical production, with major operations in the Frankfurt/Main region (Bäumler 1988; 1989).

Although Hoechst was a leading firm in different branches of the chemical industry, pressure to restructure intensified in the 1980s and 1990s. Under the leadership of its CEO Hilger, the decision was made to diversify into areas such as cosmetics, and strengthen operations in 
synthetic fibers, organic chemicals and plastics. Furthermore, the firm focused on the development of a stronger market position in North America. Since other multinational companies had already made moves to form more focused global operations by restructuring internally and expanding externally, Hoechst changed its strategy when the new CEO Dormann came into power in 1994 (Bathelt and Kappes 2008). Dormann restructured the activities in southern Hessen by shutting down older production plants, especially in the area of basic chemicals and intermediaries, and selling further production branches to other chemical firms or spinning them out (Frankfurter Allgemeine Zeitung 1996).

In the beginning, these restructuring activities were quite successful, as exemplified by increasing overall profits. However, there were substantial downsides to this development. Older production plants in need of modernization were neglected. Seemingly, investments aimed at updating these plants did not have a high priority in the 1990s. As a consequence, some politicians in southern Hessen, i.e. the firm's home region, began to view the chemical industry as a threat rather than an asset to the regional economy. Due to a number of chemical accidents, which affected several neighborhoods in Frankfurt/Main, public pressure and criticism of Dormann and the Hoechst group became very strong. In addition, restructuring processes were associated with thousands of direct job losses in the region. In the end, the labor force of Hoechst and the general public, originally supportive of Dormann's policy, developed a negative attitude toward the restructuring process. If anything, however, this public criticism led to an acceleration of the restructuring activities (Bathelt and Griebel 2001; 2002).

Similar to the development of Novartis (Zeller 2001), Dormann and his colleagues decided to concentrate on the firm's core competencies by focusing on 'life sciences', i.e. pharmaceuticals and agricultural chemicals (i.e. pesticides and fertilizers). Genetic engineering was seen to be the core technology binding both branches together and resulting in technological synergies. Many of the branches that were not related to the core 
competencies were simply sold to other firms. This encompassed, for instance, the production of cosmetics, textile fibers, technical gases, carbon activities, diagnostics, vaccines, chemical plants/equipment and numerous basic and intermediary chemical branches. Other branches were spun out into independent operations such as Ticona (technical plastics), Celanese (organic chemicals) and Provadis (specialized chemical education and training services) (Bathelt et al. 2004). Parallel to this process, the large US pharmaceuticals producer Marion Merrell Dow was acquired (1995) and the French Roussel Uclaf fully integrated (1996) to form Hoechst Marion Roussel (Frankfurter Rundschau 1995). The goal behind these acquisitions was to strengthen the pharmaceutical activities and widen international market presence.

Although these shifts were meant to mobilize possibilities for cost reductions and to increase economies of scale, they in fact created numerous problems (Bathelt and Griebel $2001 ; 2002)$. First, it seemed that decisions to sell production units were occasionally made too hasty, and were not always in the best interest of the respective operations. The production of specialty chemicals was, for instance, sold to the much smaller Swiss firm Clariant. Clariant was spun-off from Sandoz in 1995, one year before the merger of Sandoz and Ciba-Geigy into Novartis (Zeller 2001). It encompassed chemical units that were not integrated into the new Novartis group. This seemed to have caused the morale of the labor force to become further depressed, as a former manager pointed out. Second, the strategy plan that focused on life sciences did not work out as the German market, as well as others, would not accept genetically engineered foods (Hoffritz 2000). As a consequence, this strategy was given up and a new focus set to concentrate exclusively on pharmaceuticals. Later on, after the Aventis merger, the agricultural chemicals branch was sold to Bayer. 


\subsection{Restructuring of the former Rhône-Poulenc group in the Rhône-Alpes region}

Interestingly, the historical development of Rhône-Poulenc, including its structural changes during the 1990s, had some similarities with that of Hoechst (Kappes and Trucchi 2005a; 2005b). The firm's activities expanded from the production of dyestuffs into other chemical branches, such as pharmaceuticals and synthetic fibers (Cayez 1988; Laferrère 1991; Gambon 1997). As opposed to Hoechst, however, many of the new products did not result from internal innovation but were acquired from other firms. This was done through licensing arrangements, and the establishment of strategic alliances or partnerships with those firms that were in possession of the respective patents. Growth was also achieved through domestic mergers and acquisitions.

The ownership structure of Rhône-Poulenc drastically changed when the state took over control in 1982. Similar to other strategically important sectors and large companies, the French socialist government acquired the majority of shares of Rhône-Poulenc and placed government officials in the firm. Through this, the government gained control over employment relations and strategic decision-making processes. Among other goals, the state's policy was to support any action that would help maintain or expand world market shares. Moreover, decisions were supported to maintain French ownership and strengthen the company's position as a national champion. At that time, state intervention turned out to be quite advantageous in a situation of heavy economic pressure due to its old production sites and lack of investments. Subsidies from the central government helped modernize old plants that were not very profitable. These investments enabled Rhône-Poulenc to recover economically and continue to grow (Gambrelle 1995; Bonnet 2005).

In 1993, however, the company was re-privatized. The central government kept only a minority share of the group, and stepped back from its direct economic intervention policy. This re-privatization led to systematic restructuring, a process similar to that which had taken place with Hoechst. Under the leadership of Fourtou, who was voted CEO in 1986, Rhône- 
Poulenc decided to concentrate its future operations in the life sciences arena. The production program became much leaner and was reduced from 160 to only 35 product groups (Cambon 1997). As opposed to Hoechst, the group was, however, not dissolved and split up, or sold to other firms. Instead, existing divisions were restructured and recombined into a new group structure. All production activities in the area of basic and specialty chemicals were integrated into the newly formed Rhodia group. This group went public in 1998 and was transformed into an independent producer of pharmaceuticals and agricultural chemicals (Bonnet 2005).

\subsection{The Aventis merger}

In the mid 1990s, Hoechst and Rhône-Poulenc were both under pressure to expand their international market presence and faced ongoing acquisitions and mega mergers in the pharmaceutical industry (e.g. Lill 1994; Zeller 2001; Bunzenthal 2004). It seemed almost natural that discussions to merge Hoechst and Rhône-Poulenc were initiated. In order to make this decision, it was certainly helpful that Dormann was open to the Francophone life-style, and got along well with his Rhône-Poulenc counterpart Fourtou (Frankfurter Rundschau 1998). In addition, Centeon, an existing joint venture between a former US-subsidiary of Rhône-Poulenc and a Hoechst branch of the former Behringwerke in Marburg, also created a good basis for further cooperation because it served to establish initial trust between the parties. The merger of both firms into the new group Aventis took place in 1999 (Frankfurter Rundschau 1999). The initially chosen Frankfurt/Main headquarters were given up and new headquarters established in Strasbourg. Based on the media coverage, Dormann was seemingly happy to leave the region as he was being heavily criticized by Hoechst employees and the general public in the region.

Even though this was supposedly a merger between equal partners, it quickly became clear that the French side was dominant. Although Dormann remained CEO of the new Aventis group, the French influence became apparent when the French Landau was 
announced as the new CEO after the initial two-year period of the merger (Frankfurter Rundschau 2002). Critics of the merger remained skeptical regarding future developments, foreseeing this as a first step in a long-term process of further restructuring (e.g. Ochs and Sievers 1998; Hoffritz 2000). This was indeed the case (Kappes and Trucchi 2005a; 2005b). On the one hand, Aventis was under pressure because it did not have a well-developed 'pipeline' of new drugs that were in a promising stage of research, development and/or testing cycles. Therefore, the market position of the firm seemed in danger over the long term. On the other hand, there were also rumors about differences and incompatibilities between the German and French 'corporate cultures' since Hoechst had taken over Roussel Uclaf; as one former manager of the firm admitted (see, also, Frankfurter Rundschau 2001).

In 2003, the French pharmaceutical group Sanofi-Synthélabo had already announced its interest in acquiring Aventis and integrating its operations. Although being originally evaluated as a hostile takeover, the acquisition was successfully negotiated after a period of several months (Wille 2004; Salzmann 2004). In the end, Sanofi-Synthélabo and Aventis merged into the new Sanofi-Aventis group (Le Monde 2004; Kappes 2006). The new firm became a purely French-owned global player, ranked third in the world pharmaceutical market. This merger can be viewed as a continuation of the French tradition of maintaining national ownership of large groups in strategically important industries.

\section{Changing relations in the regional supplier sector}

Adjustments to new global settings in the chemical industry and the restructuring activities related to the Aventis merger caused a shift in the production and ownership structure of the former Hoechst and Rhône-Poulenc groups. Activities that were no longer part of the core competencies of Aventis were transformed into independent firms, or parts of other groups (Figure 1). As will be demonstrated, the economic consequences of this restructuring process on the supplier sector were substantial. There were also remarkable 
differences in the way supplier relations were affected by different types of suppliers, as well as the regional and national contexts.

\subsection{Shifts in the southern Hessen region}

As opposed to other chemical industry groups, such as BASF, the restructuring process of Hoechst was more drastic and was less sustainable in terms of the use of regional resources (Bathelt 1997). This was particularly the case for business segments that were split off or shut down, as well as for the regional workforce and supplier sector, both of which did not have a high priority in the decision-making process. Since the mid 1990s, numerous production branches in the region were shut down; other business segments were sold to other chemical or related firms; and mergers with other firms were pushed ahead (Bathelt and Griebel 2001; 2002). In 1997, restructuring of the formerly integrated production site of Hoechst in Frankfurt/Main had already resulted in the loss of about one third of its workforce, i.e. from 28,000 employees to a mere 21,000 within seven years (Hanack and Bartsch 1997; Papenhausen 1999).

In addition to jobs, the region also lost substantial decision-making functions. Criticism among the general public regarding the restructuring of Hoechst became increasingly louder (Wille 2004). There was, for instance, heavy criticism when the cosmetics subsidiary Jade was sold to one of its major competitors, i.e. L'Oréal from France. Criticism was also strong when the fine and specialty chemicals operations of Hoechst were sold to Clariant from Switzerland. Instead of giving the various branches time to establish their own independent market position, Hoechst focused on making short-term profits by selling these units. The result was a loss of decision-making competencies in the region and a greater dependence on external headquarters (Bathelt and Griebel 2001). The specific form of this restructuring process was by no means pre-determined or unavoidable. In comparison with the situation of Rhône-Poulenc, this restructuring was largely driven by a shareholder-value strategy which 
was pushed through by CEO Dormann (Menz et al. 1999). ${ }^{8}$ In the end, this resulted in a decreased degree of self-determination in the region regarding economic decisions about future developments.

Hoechst increasingly focused on international markets and placed less emphasis on the stagnating German market. The formerly integrated chemical plant in Frankfurt-Höchst was transformed into a chemical industrial park, i.e. the Industrial Park Höchst (IPH). Other Hoechst sites in the Frankfurt/Main region were also converted into industrial parks (Figure 2; Planungsverband Ballungsraum Frankfurt/Rhein-Main 2007). Not all impacts on the regional chemical industry were, however, negative. Re-bundling activities ${ }^{9}$ took place, initiated by the more than 80 firms that occupied the IPH site in 2004. These firms developed new strategic goals and strengthened their market positions by establishing new facilities and technologies, mobilizing innovative activities, and attracting further investments by other firms. This helped reduce the investment and innovation deficits that had built up during the 1990s. By 2004, employment at the IPH had stabilized with about 22,000 people (Strohm 2003; Wille 2004; Dietz 2007b). This was due to new investments by Aventis, former Hoechst branches such as Celanese, and new firms such as New England BioLabs, Sandoz and Solvay (Skotnik 2000; Frankfurter Rundschau 2003). ${ }^{10}$

${ }^{8}$ Dormann was not only one of the first top managers to apply this type of strategy to a major German chemical firm; he was also one of the first economists to head a multinational chemical firm in Germany.

${ }^{9}$ The term "re-bundling" refers to learning processes which combine existing and new knowledge bases with other, in part external, resources to overcome economic crises and develop a new competitive edge (Bathelt and Kappes 2008).

${ }^{10}$ In addition, the IPH will substantially benefit from the decision of Ticona to move production from near-by Kelsterbach to Höchst by 2011 (Tinnappel and Dietz 2007). Ticona has to relocate its present production plants away from Kelsterbach, as they are too close to the new Frankfurt/Main international airport. Although this is good news for the IPH, it will not stimulate additional economic growth in the region. In contrast, this relocation will even contribute to a further reduction in the number of employees in chemical production, as the 
The analysis of the data base of suppliers provided by the IPH revealed that southern Hessen was still a key location for trading firms, service providers, and other suppliers of chemical products for the Hoechst successors and IPH operations in 2000. According to this data base, 972 out of a total of 2,435 suppliers (40.0\%) were located in southern Hessen and a few adjacent counties (Bathelt et al. 2004). In terms of the type of interaction with chemical firms, our survey revealed that most relations suppliers had with IPH customers involved standardized products, while complex custom-specific transactions including individual training, after-sales services or joint technical adjustments were rare (Bathelt and Griebel $2001 ; 2002)$. This is not, however, unusual in the chemical industry. In asking questions about the type of interaction that typically occurred with IPH customers, it turned out that $72.6 \%$ of all firms surveyed engaged in delivery-related issues, 56.0\% in technical adjustments and $42.9 \%$ in the coordination of production. While delivery-related issues revolved around price, amount and time of delivery, technical adjustments and coordination involved more intensive interaction. Technical adjustments, for instance, included adjustments in machinery to accommodate the integration of supplies into the production process, while coordination issues were related to questions such as when to start batch production or how exactly to accommodate for the required material flows. Only $19.0 \%$ of all suppliers were engaged in systematic feedbacks related to former interaction and problem-solving activities. Upon closer investigation, there were, however, significant differences between different types of suppliers. Table 1 lists those firms that indicated that their IPH sales share had increased $\left(n_{1}=29\right)$ or decreased $\left(\mathrm{n}_{2}=38\right)$ between 1991/1992 and 1999/2000. Firms which had no changes in their

new facilities with 750 employees will initially employ 100 people less than before (Dietz 2007a; Frankfurter Rundschau 2007). Moreover, Clariant announced in 2007 that production at the Industriepark Griesheim will be shut down, affecting about 50 employees. The firm also decided to give up its share in the provision of services to other firms in the industrial park because the location had not been successful in acquiring new tenants in recent years (Dietz 2007b). 
IPH sales share $\left(\mathrm{n}_{3}=17\right)$ were not included. While firms with a decreasing IPH sales share were primarily involved in delivery-related interactions, suppliers with a growing IPH sales share had a significantly stronger focus on systematic feedbacks and joint problem-analysis (Table 1). Our interviews confirmed, on the one hand, that firms which were more successful in maintaining strong business relations, or strengthening their sales position with IPH customers, had placed a stronger emphasis on complex, knowledge-intensive interactions and services which required in-depth technical adjustments and ongoing communication. On the other hand, less successful suppliers had primarily engaged in simple transactions with their IPH customers focusing on price and delivery issues, while neglecting complex types of interaction which involved timely technical adjustments and knowledge exchange.

Hildebrand (2006) pointed out that the overall supplier relations became more difficult over time as price pressure originating from chemical customers increased. Seemingly, practices similar to those in the automobile industry requesting that suppliers lower their prices in consecutive stages have become more widespread in the chemical industry. Overall, it appeared that the role of supplier competence was sometimes underestimated by users in the chemical industry. The interviews with Frankfurt/Main chemical suppliers indicated that some were able to develop specialized competencies over time by having intensive interaction and engaging in learning processes with their customers. Through this, they were able to adjust to structural changes and acquire new customer groups in different markets later on.

Today, many firms evaluate the dissolution of the former Hoechst group and the subsequent restructuring of the chemical production complex more positively than during the 1990s. Several of the managers of former Hoechst branches interviewed mentioned that they had to face stronger competition than in the past but that they were also more specialized and well-prepared to face worldwide competitors. The new structure would enable them to react quicker and more flexibly towards changing market requirements compared to the "old, rigid Hoechst days", as one former manager of Hoechst described the past structure. 


\subsection{Shifts in the Rhône-Alpes region}

Due to external pressures, the French Rhône-Poulenc group was also restructured during the mid 1990s. As opposed to Hoechst, restructuring activities initially concentrated on internal reorganization. After the re-privatization of the group, the different production branches were recombined into a holding structure. Instead of selling production branches individually to other firms or closing them down, Rhône-Poulenc established a new chemical company, i.e. Rhodia, which incorporated all activities that did not fit the defined core competencies. Rhodia took over most of the former chemical branches in the Rhône-Alpes region, located around Lyon and Grenoble (Figure 3; Laferrère 1991). Due to the tight economic situation and pressure from the capital owners, Rhodia had to further restructure its activities in subsequent years. This was due to the fact that many plants had older machinery and needed to make investments in new equipment. As a consequence, the integrated production structure was partially dissolved, and several units were sold to other firms, especially to raise capital for necessary investments.

Formerly integrated production sites were opened up and industrial park structures established in Roussillon, St.-Clair-du-Rhône and Le Pont-de-Clair (Figure 3). Many of the new tenants of the chemical parks only established branch operations that were controlled from their headquarters located elsewhere. Similar to the situation in southern Hessen, decision-making competencies were partially relocated. As opposed to Hoechst, the restructuring process in the Rhône-Alpes region is still at a relatively early stage and has not resulted in negative impacts that are comparable to those in southern Hessen. Even though future restructuring is unclear at this point (Kappes and Trucchi 2005a; 2005b), further substantial effects on employment and supplier relations can be expected, as the recent closures of Huntsman and Arkema indicated (ICIS Chemical Business 2006; SpecialChem 2007). 
Based on the number of employees, the chemical industry is one of the most important industries in the Rhône-Alpes region. Restructuring has, thus far, not yet had a substantial effect on regional employment. The closure and reduction of production units in the chemical industry (including pharmaceuticals) has only caused a modest decrease in employment from 64,900 to 64,100 between 1999 and 2005 (Assedic 2006). As opposed to the situation in southern Hessen, where many suppliers and service providers were successful in restructuring their production programs, the Rhône-Alpes firms have had more problems. In the case of 22 out of a total of 41 suppliers interviewed, the sales share with Rhône-Poulenc successors decreased between 1994/95 and 2004/05. Only a few firms were able to increase their sales share with their key customers. Although the number of firms interviewed was too small to conduct statistical tests, some general trends can be identified. In terms of the complexity of interactions between the former Rhône-Poulenc suppliers and their new customers, about $60 \%$ of the suppliers mentioned that their business relations were often customized; $55 \%$ said that they conducted both assembly and maintenance jobs at their customers' sites (Table 2; Table 3). This indicates that producer-user interaction often involved complex elements rather than just sales procedures. Compared to firms with decreasing sales shares with their RhônePoulenc successors, firms with growing shares seemed to differ particularly with respect to the degree of customized jobs offered. Only a small percentage of firms with decreasing sales share sold customized products and services (Table 2). As our interviews illustrated, assembly and installation activities of the latter suppliers were often done strictly according to the instructions of the customers, with little supplier initiative allowed or innovation involved, even when customized supplies were delivered. One manager mentioned that, "[t]hese people send us an advertisement, an order which we respond to according to their specifications. They determine the rules since they are also the users ... They direct the process and this is why we follow them, ..., we do not create or change anything by ourselves. We follow their 
system.” (translated from French). Opportunities for interactive learning and the development of specialized competencies were, thus, limited for the former Rhône-Poulenc suppliers.

Managers of suppliers explicitly pointed out that they had difficulties adjusting to the new structures of the chemical industry. Although few interviewees said this directly, our analysis indicated that this seemed, at least, partially related to the fact that the suppliers focused on manufacturing activities with few accompanying service activities. A comparison of the former Rhône-Poulenc suppliers in Rhône-Alpes with the former Hoechst suppliers in southern Hessen also supports this observation (Table 3). It shows that the proportion of German chemical suppliers that were involved in additional consultation activities, personnel training at the customers' sites and after-sales services was significantly higher than that of the French suppliers. In contrast, the former Rhône-Poulenc suppliers conducted significantly more manufacturing jobs, such as assembly or maintenance activities at the customers' sites with fewer complex service relations involved at a similar stage of restructuring (Table 2). Our interviews provided evidence that multidimensional relationships between suppliers and customers, which were not merely focused on manufacturing, were particularly important for the generation of specialized competencies, thus strengthening the position of southern Hessen suppliers as opposed to Rhône-Alpes suppliers. ${ }^{11}$

Another problem present in the Rhône-Alpes region was related to the reorganization of the local purchasing departments of the chemical customers. As in the case of Rhodia, some important firms relocated their purchasing departments from the various production sites to other locations. Although these shifts aimed to increase efficiency and concentrate

\footnotetext{
${ }^{11}$ The relative importance of standardized supplies in southern Hessen compared to the Rhône-Alpes region is not at odds with the above statements. It simply reflects the fact that the survey of former Hoechst suppliers and service providers also included some trade firms which conducted a substantial part of their business in the form of standardized deliveries.
} 
competencies, this seemingly had a negative impact on the production sites. The lack of spatial proximity between production and purchasing divisions caused the development of different expectations regarding the needs in production. According to our research, local knowledge about the required supplier competence was often ignored when purchasing decisions were made. As numerous interviewees emphasized, the centralized purchasing divisions of customers tended to make their decisions based on price considerations at the expense of quality requirements. This seemingly led to problems in production and created an additional burden for the regional suppliers.

\section{Conclusions}

This paper presents a relational view toward understanding the effects of international mergers and related regional deindustrialization processes. Different from some of the literature on regional restructuring that aggregates economic developments at the regional level and treats regions as if they are agents, this approach leads us to analyze the effects of economic concentration processes on regional supplier linkages at the individual firm level. Moreover, this analysis views economic interaction as social interaction which is shaped by communication and adjustments with other agents, and not just driven by individual optimization considerations. Using the example of the merger of the former Hoechst and Rhône-Poulenc groups into Aventis, this paper investigates how supplier relations have been affected by restructuring processes. Instead of investigating those divisions of the former Hoechst and Rhône-Poulenc groups that became the core of Aventis, our study focuses on other divisions that were split off as they were considered to be less important, and analyzes the effects these restructuring processes had on the regional supplier sector. The analysis particularly draws upon the two former core regions of chemical production, i.e. southern Hessen, Germany and Rhône-Alpes, France. 
The restructuring process that led to the Aventis merger began in the mid 1990s. In the case of southern Hessen, Hoechst began to dissolve its formerly integrated production structure by selling chemical production branches to other firms or by closing the respective units. Following a shareholder-value strategy, the firm fully concentrated on life sciences. Internal reorganization provided the starting point for the restructuring of Rhône-Poulenc, which was geared toward increasing the profitability of the group. It was only shortly before the Aventis merger, that all chemical activities apart from life sciences were combined and split off into a new firm, i.e. Rhodia. It was not until then that substantial restructuring of chemical production in the Rhône-Alpes region began. Overall, the restructuring process of Rhône-Poulenc's former chemical branches started later than that of Hoechst and is still underway. It can be expected that this process will have further negative effects on the RhôneAlpes region, since some of the former chemical branches of Rhône-Poulenc are still characterized by a need for modernization. Although both regions are embedded in different national systems and development paths, they share a number of parallels. We observed, for instance, similar adjustment processes in the regional supplier sectors. From our analysis, we conclude that, notwithstanding different traditions, lock-ins and systems, suppliers in both cases have benefited from the development of relational proximity with their major customers.

In southern Hessen and Rhône-Alpes, the Aventis merger and associated restructuring led to substantial job losses and a reduction of regional supplier linkages. Formerly integrated production sites of chemical production were opened up and transformed into industrial parks (Figure 2; Figure 3), where new tenants established production networks based on the former Rhône-Poulenc and Hoechst operations. At the same time, new opportunities have also emerged as firms began to re-bundle their assets and recombine them to produce new goods and services, or access new customer groups. Suppliers which intensively interacted with their chemical customers, involving additional services and joint problem-solving, were able to develop specialized competencies that allowed them to adjust to a changing economic 
environment. Our research also indicated that the development of competencies was stronger and more widespread among suppliers in southern Hessen compared to the Rhône-Alpes region. Among other reasons, this was due to the fact that suppliers and service providers in southern Hessen had developed linkages which involved more frequent knowledge-intensive interaction, joined problem-solving and after-sales services, or dynamic relational proximity. In Rhône-Alpes, many suppliers suffered from the restructuring as their sales shares with regional customers decreased. These negative consequences, which were due to the Aventis merger clearly posed threats to the regional economies in southern Hessen and Rhône-Alpes. Although our empirical results indicate that more research is required to fully understand the relationship between relational proximity and economic success, we have shown that quantitative and qualitative research methods can be fruitfully combined to investigate this issue.

Our research also indicates that the chemical firms did not pay much attention to the supply-chain side, beyond managing costs. Especially in the Rhône-Alpes region, the importance of suppliers as partners in processes of knowledge generation was largely underestimated or overlooked. According to our interviews, it appears that increases in productivity can be realized during processes of restructuring, if existing competencies and capabilities of suppliers and service providers are recognized and used. Only some of the suppliers interviewed, especially in southern Hessen, were seemingly able to intensify interfirm relations and develop their competencies further. They were successful in acquiring new customer and market segments, and strengthen their sales basis with chemical customers.

Overall, this leads to a number of policy implications regarding corporate and regional economic policies, in order to avoid wider crises symptoms which could occur due to economic concentration processes. From a corporate view, upgrading in the supplier sector, coupled with conscious attempts to create relational proximity with core customers, might be an important strategy to strengthen a supplier's competence and ability to adjust flexibly to 
changes in the economic environment. This requires that suppliers scrutinize their portfolio of products and services in order to extend or introduce operations that enable a closer, more knowledge-intensive, technologically sophisticated exchange. Of course, the possibilities for these types of shifts in the production program depend upon a firm's stage in the value chain.

Although regional planning in southern Hessen begins to realize that the chemical industry is an important asset to the region in terms of employment and technology development, and that large growth spurts cannot be expected in this industry under the present conditions (Planungsverband Ballungsraum Frankfurt/Rhein-Main 2007), comprehensive support policies that include the supplier sector do not exist. From the point of regional policy, our research suggests that policy makers should not underestimate or overlook problems resulting from internationalization processes. An important policy implication, which is in line with traditional research on old industrialized regions, is that it is important for policy makers to not only direct their policies toward successful high-end producers, attention should also be paid to the supplier sector in well-established manufacturing industries, for instance by establishing precautionary networking policies. To help these suppliers and service providers cope with unforeseen ruptures following international mergers and acquisitions, regional policy could actively help develop ideas to upgrade production programs, make connections with consulting firms or create inter-firm networks for information exchange.

\section{Acknowledgements}

Earlier versions of this paper were presented at the Fifth Proximity Congress on « La proximité, entre interaction et institution » in Bordeaux, 28 - 30 June 2006 and the RGS-IBG Annual International Conference in London, 30 August - 1 September 2006. We would like to thank the participants of these conferences, particularly Stephen Appold, for critical remarks and suggestions. We are also indebted to Nicole Kogler, Diane Perrons, Silvia Posocco and Clare Wiseman for valuable comments on earlier drafts of this paper. 
Furthermore, this paper has substantially benefited from constructive criticism which we received from three anonymous reviewers and Michael Samers.

\section{References}

Amin, A. and Cohendet, P. (2004): Architectures of Knowledge: Firms, Capabilities, and Communities. Oxford, New York: Oxford University Press.

Archibugi, D., Howells, J. and Michie, J. (1999): Innovation systems and policy in a global economy. In: Archibugi, D., Howells, J. and Michie, J. (Eds.): Innovation Policy in a Global Economy. pp. 1-17. Cambridge: Cambridge University Press.

Assedic - Association pour l'emploi dans l'industrie et le commerce (2006): Statistique annuelle de l'emploi salarié au 31 décembre (Annual Employment Statistics, December 31). Métropole - Région - NES 36 (nomenclature NAF 2003). Paris (URL: http://info.assedic.fr/unistatis/index.php, date accessed: December 10, 2006)

Atherton, A. (2003): Examining cluster formation from the 'bottom-up': an analysis of four cases in the North of England'. Environment and Planning C: Government and Policy 21: 21-35.

Bäumler, E. (1988): Die Rotfabriker: Familiengeschichte eines Weltunternehmens (The Red Workers: Family History of a World Company). München: Piper.

Bäumler, E. (1989): Farben, Formeln, Forscher: Hoechst und die Geschichte der industriellen Chemie in Deutschland (Hoechst and the History of Industrial Chemistry in Germany). München: Piper.

Bathelt, H. (1997): Chemiestandort Deutschland. Technologischer Wandel, Arbeitsteilung und geographische Strukturen in der Chemischen Industrie (German Chemical Industry. Technological Change, the Division of Labor and Geographical Structure). Berlin: Edition Sigma - Bohn.

Bathelt, H. (2006): Geographies of production: growth regimes in spatial perspective 3 toward a relational view of economic action and policy. Progress in Human Geography 30: $223-236$.

Bathelt, H., Depner, H. and Griebel, K. (2004): Chemische Industrie: Integrierte Standorte im Wandel (Chemical industry: restructuring of integrated production sites). In: LeibnitzInstitut für Länderkunde (Eds.): Nationalatlas Bundesrepublik Deutschland. Band 8: Unternehmen und Märkte. pp. 68-71. München: Elsevier. 
Bathelt, H. and Glückler, J. (2003): Toward a relational economic geography. Journal of Economic Geography 3: 117-144.

Bathelt, H. and Griebel, K. (2001): Die Struktur und Reorganisation der Zulieferer- und Dienstleisterbeziehungen des Industriepark Höchst (IPH) (Reorganization of Supplier Relations After Hoechst's Restructuring Into Aventis). IWSG Working Papers 02-2001. Frankfurt/Main: Institut für Wirtschafts- und Sozialgeographie, Universität Frankfurt/Main (URL: http://www.geo.unifrankfurt.de/ifh/Forschung/Publikationen/Archiv/downloads/IWSG/IWSG_02-2001.pdf, date accessed: September 3, 2007).

Bathelt, H. and Griebel, K. (2002): Restructuration de l'ancien site principal du groupe Hoechst après sa fusion avec Rhône-Poulenc pour créer Aventis (Restructuring of the former production sites of Hoechst after the merger with Rhône-Poulenc into Aventis). Hommes et Terres du Nord 2002/4: 4-13.

Bathelt, H. and Kappes, K. (2008): Regional deindustrialization and re-bundling: evidence from the merger of the former German Hoechst and French Rhône-Poulenc groups. In: European Planning Studies 16: forthcoming.

Beynon, H., Hudson, R. and Sadler, D. (1994): A Place Called Teesside: A Locality in a Global Economy. Edinburgh: Edinburgh University Press.

Bluestone, B. and Harrison, B. (1982): The Deindustrialization of America. New York: Basic Books.

Bonnet, J. (2005): De Rhône-Poulenc à Sanofi-Aventis: intérêts régionaux et logiques mondiales (From Rhône-Poulenc to Sanofi-Aventis: regional interests and global logic). L'Information Géographique 2: 117-131.

Boschma, R. A. (2005): Proximity and innovation: a critical assessment. Regional Studies 39: $61-74$.

Bunzenthal, R. (2004): Teure Forschung forciert Pharma-Fusionen (Expensive research spurs pharma mergers). Frankfurter Rundschau, January 28, p. 11.

Cambon, P. (1997): Rhône-Poulenc - Hundert Jahre im Dienste der Weltgesundheit (RhônePoulenc - One hundred years serving global health). Label France 28: 20-21.

Cayez, P. (1988): Rhône-Poulenc 1895-1975. Paris: Armand Colin.

Chapman, K. (2005): From "growth centre" to "cluster": restructuring, regional development, and the Teesside chemical industry. Environment and Planning A 37: 597-615. 
Chesnais, F. (1993): The French national innovation system. In: Nelson, R. R. (Ed.): National Innovation Systems: A Comparative Analysis. pp. 192-229. Oxford: Oxford University Press.

Clark, G. L. (1982): Rights, property, and community. Economic Geography 58: 120-138.

Clark, G. L. (1983): Fluctuations and rigidities in local labor markets. Part 2: reinterpreting relational contracts. Environment and Planning A 15: 365-377.

Clark, G. L. and Tracey, P. (2004): Global Competitiveness and Innovation: An AgentCentred Perspective. Houndsmill, New York: Palgrave Macmillan.

Dicken, P., Kelly, P. F., Olds, K. and Yeung, H. W.-c. (2001): Chains and networks, territories and scales: towards a relational framework for analysing the global economy. Global Networks 1: 89-112.

Dietz, P. (2007a): Duell zweier ungleicher Schwestern (Duel of two unequal sisters). Frankfurter Rundschau, July 28, pp. D2-D3.

Dietz, P. (2007b): Abkehr vom Chemiepark (Turning away from the chemical park). Frankfurter Rundschau, November 23, p. D4.

Frankfurter Allgemeine Zeitung (1996): Grundlegender Umbau eines traditionsreichen Konzerns (Fundamental restructuring of a traditional company). January 4, p. 13.

Frankfurter Rundschau (1995): Hoechst-Fusionspläne stoßen auf deutliche Skepsis (Hoechst merger leads to skepticism). March 2, p. 15.

Frankfurter Rundschau (1998): Hoechst und Rhône-Poulenc verordnen sich Fusion (Hoechst and Rhône-Poulenc prescribe themselves a merger). December 2, p. 13.

Frankfurter Rundschau (1999): Aventis-Fusion geht im November über die Bühne (Aventis merger to take place in November). May 18, p. 13.

Frankfurter Rundschau (2001): Aventis Crop Science: “Tiefer Riss trennt das Unternehmen" (Aventis Crop Science: “Deep rupture splits the firm”). February 16, p. 13.

Frankfurter Rundschau (2002): Aventis-Chef Jürgen Dormann tritt überraschend zurück (Aventis leader Dormann surprisingly steps back). March 3, p. 9.

Frankfurter Rundschau (2003): Statt Dreieck eine Achse (New axis instead of triangle). March 10, p. 19.

Gambrelle, F. (1995): Innover pour la vie. Rhône-Poulenc 1895-1995 (Innovation for life. Rhône-Poulenc 1895-1995). Clichy: Public Histoire.

Grabher, G. (1993): Rediscovering the social in the economics of interfirm relations. In: Grabher, G. (Ed.): The Embedded Firm. On the Socioeconomics of Industrial Networks. pp. 1-31. London, New York: Routledge. 
Granovetter, M. (1985): Economic action and economic structure: the problem of embeddedness. American Journal of Sociology 91: 481-510.

Greco, L. (2004a): Industrial Redundancies: A Comparative Analysis of the Chemical and Clothing Industries in the UK and Italy. Aldershot: Ashgate.

Greco, L. (2004b): An institutionalist approach to redundancies in the chemical industry: the cases of Teesside (UK) and Brindisi (Italy). European Urban and Regional Studies 11(2): 141-155.

Hall, P. A. and Soskice, D. (2001): An introduction to varieties of capitalism. In: Hall, P. A. and Soskice, D. (Eds.): Varieties of Capitalism: The Institutional Foundations of Comparative Advantage. pp. 1-68. Oxford, New York: Oxford University Press.

Hanack, P. and Bartsch, M. (1997): Die Farbwerke als Flickenteppich (The dyestuff factory like a patchwork blanket). Frankfurter Rundschau, December 3, p. 23.

He, S. (2006): Clusters, Structural Embeddedness, and Knowledge: A Structural Embeddedness Model of Clusters. Paper presented at the DRUID-DIME Winter PhD Conference, January 26-28, Skoerping (URL:

http://www.druid.dk/conferences/winter2006/papers/dw2006-660.pdf, date accessed: June 1, 2006).

Henderson, J., Dicken, P., Hess, M., Coe, N. and Yeung, H. W.-c. (2002): Global production networks and the analysis of economic development. Review of International Political Economy 9: 436-464.

Hildebrand, J. (2006): Massiver Preisdruck auf Zulieferer (Massive price pressure on suppliers). Frankfurter Rundschau, January 28, p. 11.

Hoffritz, J. (2000): Suche nach dem neuen Traum (Searching for the new dream). Die Zeit, November 23, p. 25-26.

ICIS Chemical Business (2006): Huntsville expands Asian effects. October 30 (Web Site: http://www.icis.com/Articles/2006/10/27/2017185/huntsman-expands-asianeffects.html, date accessed: September 4, 2007).

Kappes, K. (2006): Vom Verbundstandort zum Industriepark: Die chemische Industrie in Deutschland und Frankreich (From integrated production sites toward industrial parks: the chemical industry in Germany and France). Praxis Geographie 36(1): 23-27.

Kappes, K. and Trucchi, E. (2005a): "Elefantenhochzeiten” französischer und deutscher Großunternehmen: das Beispiel Aventis (Giant mergers between German and French corporate groups: the example of Aventis). In: Georg-Eckert-Institut für internationale Schulbuchforschung (Eds.): Deutsch-französische Materialien: Deutschland und 
Frankreich auf dem Weg in ein neues Europa. Online-Publication (Web Site: http://www.deuframat.de, date accessed: June 1, 2006).

Kappes, K. and Trucchi, E. (2005b): Les « mariages de géants » entre entreprises françaises et allemandes: l'exemple d'Aventis (Giant mergers between German and French corporate groups: the example of Aventis). In: Georg-Eckert-Institut für internationale Schulbuchforschung (Eds.): Deutsch-französische Materialien: Deutschland und Frankreich auf dem Weg in ein neues Europa. Online-Publication (Web Site: http://www.deuframat.de, date accessed: June 1, 2006).

Katzenstein, P. J. (1987): Policy and Politics in West Germany: The Growth of a Semisovereign State. Phildelphia: Temple University Press.

Keck, O. (1993): The national system of technical innovation in Germany. In: Nelson, R. R. (Ed.): National Innovation Systems: A Comparative Analysis. pp. 115-157. Oxford: Oxford University Press.

Kobiela, F. (2003): Unternehmensgründungen ehemaliger Mitarbeiter der Hoechst AG (Startup and Spin-off Activities Originating From the Former Hoechst Headquarters). Unpublished Diplom Thesis, Frankfurt/Main: Institut für Wirtschafts- und Sozialgeographie, Universität Frankfurt/Main.

Laferrère, M. (1991): Les industries chimiques dans la région Rhône-Alpes (The chemical industry in the Rhône-Alpes region). In: Brücher, W., Grotz, R. and Pletsch, A. (Eds.): Géographie industrielle de la France et de la République fédérale d'Allemagne dans les années quatre-vingt. pp. 287-307. Frankfurt/Main: Diesterweg.

Le Monde (2004): Sanofi-Aventis devient le troisième groupe pharmaceutique mondial (Sanofi-Aventis becomes the third-largest pharmaceutical group of the world). April 27, p. 19.

Lill, U. (1994): Der Pharmamarkt im Übernahmefieber (Merger fever in the pharmaceutical market). Frankfurter Allgemeine Zeitung, August 19, p. 11.

Lundvall, B.-Å. (1992): Introduction. In: Lundvall, B.-Å. (Ed.): National Systems of Innovation: Towards a Theory of Innovation and Interactive Learning. pp. 1-19. London: Pinter.

Lundvall, B.-Å. and Maskell, P. (2000): Nation states and economic development: from national systems of production to national systems of knowledge creation and learning. In: Clark, G. L., Feldman, M. P. and Gertler, M. S. (Eds.): The Oxford Handbook of Economic Geography. pp. 353-372. Oxford: Oxford University Press. 
Martin, R. and Sunley, P. (2006): Path dependence and regional economic evolution. Journal of Economic Geography 6: 35-437.

Massey, D. (1984): Spatial Divisions of Labor: Social Structures and the Geography of Production. London: Macmillan.

Massey, D. and Meegan, R. (1982): The Anatomy of Job Loss. London: Methuen.

Menz, W., Becker, S. and Sablowski, T. (1999): Shareholder-Value gegen

Belegschaftsinteressen: Der Weg der Hoechst-AG zum “Life-Sciences”-Konzern (Shareholder Value Against Employees' Interests: The Development of Hoechst AG into a Life Sciences Group). Hamburg: VSA.

Myrdal, G. (1957): Economic Theory and Underdeveloped Regions. London: Duckworth.

Nelson, R. R. and Winter, S. G. (1982): An Evolutionary Theory of Economic Change. Cambridge (MA): Harvard University Press.

Nooteboom, B. (2000): Learning and Innovation in Organizations and Economies. Oxford: Oxford University Press.

Ochs, J. and Sievers, M. (1999): Aventis? "Wir sagen weiter Hoechst" (Aventis? "We will still say Hoechst"). Frankfurter Rundschau, July 14, p. 3.

Papenhausen, V. (1999): Neue Chancen für Zulieferer (New opportunities for suppliers). Frankfurter Rundschau, June 2, p. 30.

Planungsverband Ballungsraum Frankfurt/Rhein-Main (2007): Branchenreport Chemie und Pharmazie FrankfurtRheinMain (Industry Report of the Chemical and Pharmaceutical Industry in FrankfurtRheinMain). Frankfurt/Main.

Rallet, A. and Torre, A. (1999): Is geographical proximity necessary in the innovation networks in the era of the global economy? GeoJournal 49: 373-380.

Ruigrok, W. and van Tulder, R. (1995): The Logic of International Restructuring. London: Routledge.

Salzmann, B. (2004): Aventis, die Letzte (Aventis, the last curtain). Frankfurter Rundschau, June 11, p. 13.

Sayer, A. (1992): Method in Social Science. London: Routledge.

Schumann, M., Baethge-Kinsky, V., Kuhlmann, C. and Neumann, U. (1994): Trendreport Rationalisierung. Automobilindustrie, Werkzeugmaschinenbau, Chemische Industrie (Rationalization Trends in the Automobile, Machinery Tool and Chemical Industries). Berlin: Edition Sigma - Bohn.

Skotnik, M. (2000): Hochbetrieb im Industriepark Höchst (Boom in the industrial park Höchst). Frankfurter Rundschau, May 24, p. 32. 
SpecialChem (2007): Arkema 2007 Half-Year Results. August 14 (Web Site:

http://www.specialchem4coatings.com/news-trends/displaynews.aspx?id=7677, date accessed: September 3, 2007).

Strohm, T. (2003): Werkeln an der Baustelle Industriepark (Industrial park under construction). Frankfurter Rundschau, December 18, p. 15.

Sturgeon, T. J. (2002): Modular production networks: a new American model of industrial organization. Industrial and Corporate Change 11: 451-496.

Tinnappel, F. and Dietz, P. (2007): Ticona zieht nach Höchst (Ticona moves to Höchst). Frankfurter Rundschau, July 28, p. D1.

Torre, A. and Rallet, A. (2005): Proximity and localization. Regional Studies 39: 47-59.

Wille, J. (2004): Das Erbe der Rotfabriker (The heritage of the red works). Frankfurter Rundschau, January 31, p. 3.

Yeung, H. W.-c. (2005): Rethinking relational economic geography. Transactions of the Institute of British Geographers NS 30: 37-51.

Zeller, C. (2001): Globalisierungsstrategien - Der Weg von Novartis (Globalization Strategies - The Path of Novartis). Berlin, Heidelberg: Springer.

Zeller, C. (2004): North Atlantic innovative relations of Swiss pharmaceuticals and the importance of regional biotech arenas. Economic Geography 80: 83-111. 
Table 1. Type of interaction of former Hoechst suppliers with their IPH customers, 1999/2000 (Source: survey results)

\begin{tabular}{|c|c|c|c|c|}
\hline $\mathrm{i}$ & $\begin{array}{l}\text { Type of interaction } \\
\text { conducted }\end{array}$ & $\begin{array}{c}\text { Share of firms with } \\
\text { growing IPH }{ }^{1)} \\
\text { sales share } \\
\text { 1991/92-1999/2000 } \\
\text { p }_{1 i}\left(n_{1}=29\right)\end{array}$ & 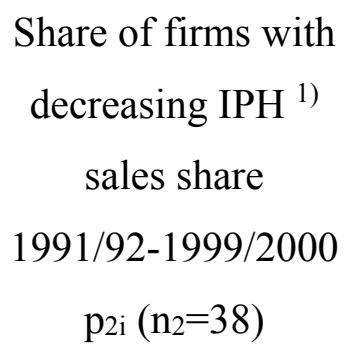 & Test statistic $\left.\tau_{\mathrm{i}}{ }^{2}\right)$ \\
\hline 1 & Delivery-related issues & $55.2 \%$ & $83.8 \%$ & $-2.60^{* * *}$ \\
\hline 2 & $\begin{array}{l}\text { Coordination of } \\
\text { production }\end{array}$ & $58.6 \%$ & $43.2 \%$ & 1.26 \\
\hline 3 & Technical adjustments & $65.5 \%$ & $48.6 \%$ & 1.41 \\
\hline 4 & Systematic feedback & $34.5 \%$ & $8.1 \%$ & $2.67^{* * *}$ \\
\hline 5 & $\begin{array}{l}\text { Problem-analysis/ } \\
\text {-solving }\end{array}$ & $31.0 \%$ & $13.5 \%$ & $1.71^{*}$ \\
\hline & $\begin{array}{l}=\text { Industrial Park Höchst } \\
=\frac{p_{1 i}-p_{2 i}}{\sqrt{\frac{p_{1 i} \cdot\left(1-p_{1 i}\right)}{n_{1}}+\frac{p_{2 i}}{}}}\end{array}$ & $\overline{\overline{\left.p_{2 i}\right)}}$ & & \\
\hline & ance levels: ${ }^{* * *}=1 \%,{ }^{* *}=5 \%$, & & & \\
\hline
\end{tabular}


Table 2. Complexity of interaction of former Rhône-Poulenc suppliers with their Rhône-Alpes customers, 2004/05 (Source: survey results)

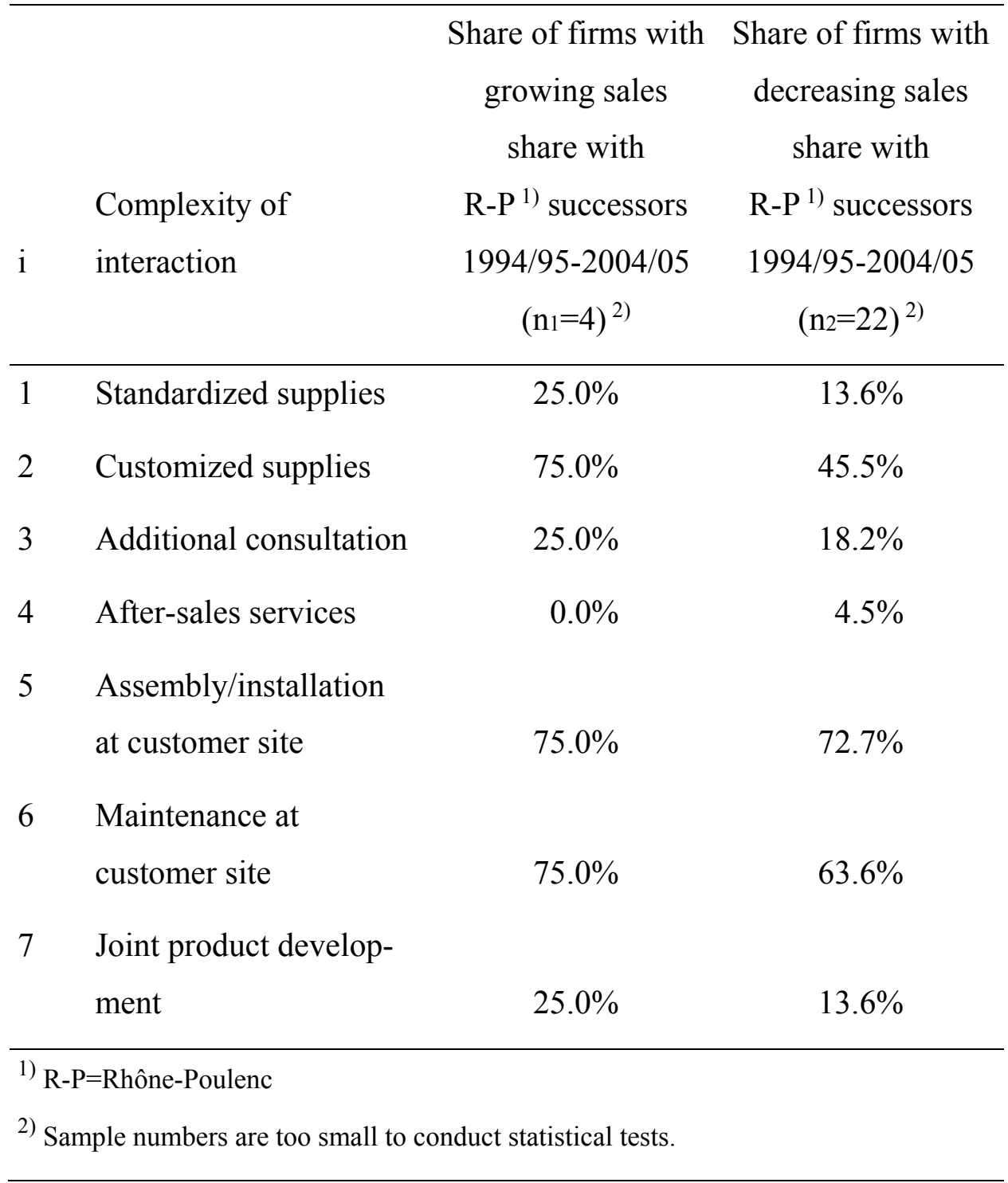


Table 3. Complexity of interaction of former Rhône-Poulenc and Hoechst suppliers with their customers in Rhône-Alpes, 2004/05 and southern Hessen, 1999/2000, respectively (Source: survey results)

\begin{tabular}{|c|c|c|c|c|c|}
\hline i & $\begin{array}{l}\text { Complexity of } \\
\text { interaction }\end{array}$ & $\begin{array}{c}\text { Share of suppliers } \\
\text { in Rhône-Alpes } \\
2004 / 05 \\
\text { p }_{1 \mathrm{i}}\left(\mathrm{n}_{1}=41\right)\end{array}$ & $\begin{array}{c}\text { Share of suppliers } \\
\text { in southern Hessen } \\
1999 / 2000 \\
\mathrm{p}_{2 \mathrm{i}}\left(\mathrm{n}_{2}=105\right)\end{array}$ & Test statistic & $\tau_{\mathrm{i}}^{1)}$ \\
\hline 1 & Standardized supplies & $17.1 \%$ & $38.1 \%$ & -2.78 & $* * *$ \\
\hline 2 & Customized supplies & $58.5 \%$ & $51.4 \%$ & 0.78 & \\
\hline 3 & Additional consultation & $26.8 \%$ & $53.3 \%$ & -3.13 & $* * *$ \\
\hline 4 & $\begin{array}{l}\text { Training personnel at } \\
\text { customer site }\end{array}$ & $4.9 \%$ & $16.2 \%$ & -2.29 & $* *$ \\
\hline 5 & After-sales services & $2.4 \%$ & $27.6 \%$ & -5.07 & $* * *$ \\
\hline 6 & $\begin{array}{l}\text { Assembly/installation } \\
\text { at customer site }\end{array}$ & $56.1 \%$ & $33.3 \%$ & 2.53 & \\
\hline 7 & $\begin{array}{l}\text { Maintenance at } \\
\text { customer site }\end{array}$ & $53.7 \%$ & $30.5 \%$ & 2.58 & \\
\hline 8 & $\begin{array}{l}\text { Joint product develop- } \\
\text { ment }\end{array}$ & $17.1 \%$ & $5.7 \%$ & 1.81 & \\
\hline & $\begin{array}{c}=\frac{p_{1 i}-p_{2 i}}{\sqrt{\frac{p_{1 i} \cdot\left(1-p_{1 i}\right)}{n_{1}}+\frac{p_{2 i}}{}}} \\
\text { icance levels: }{ }^{* * *}=1 \%,{ }^{* *}=5 \%\end{array}$ & $\frac{\overline{\left.p_{2 i}\right)}}{\overline{p \%}}$ & & & \\
\hline
\end{tabular}


Figure 1. Regional effects of international mergers

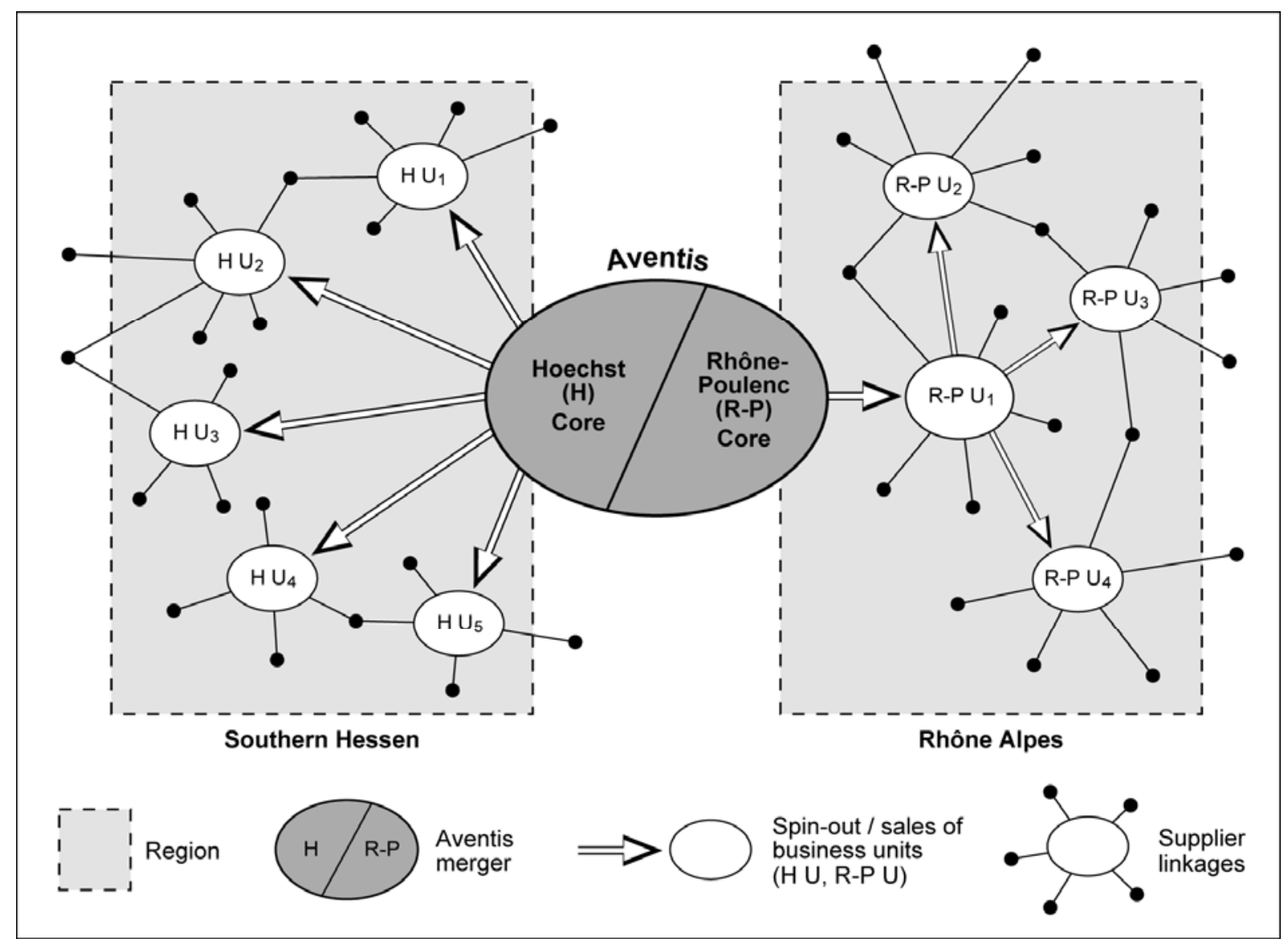


Figure 2. Structure of the former Hoechst sites in the southern Hessen region, 2006

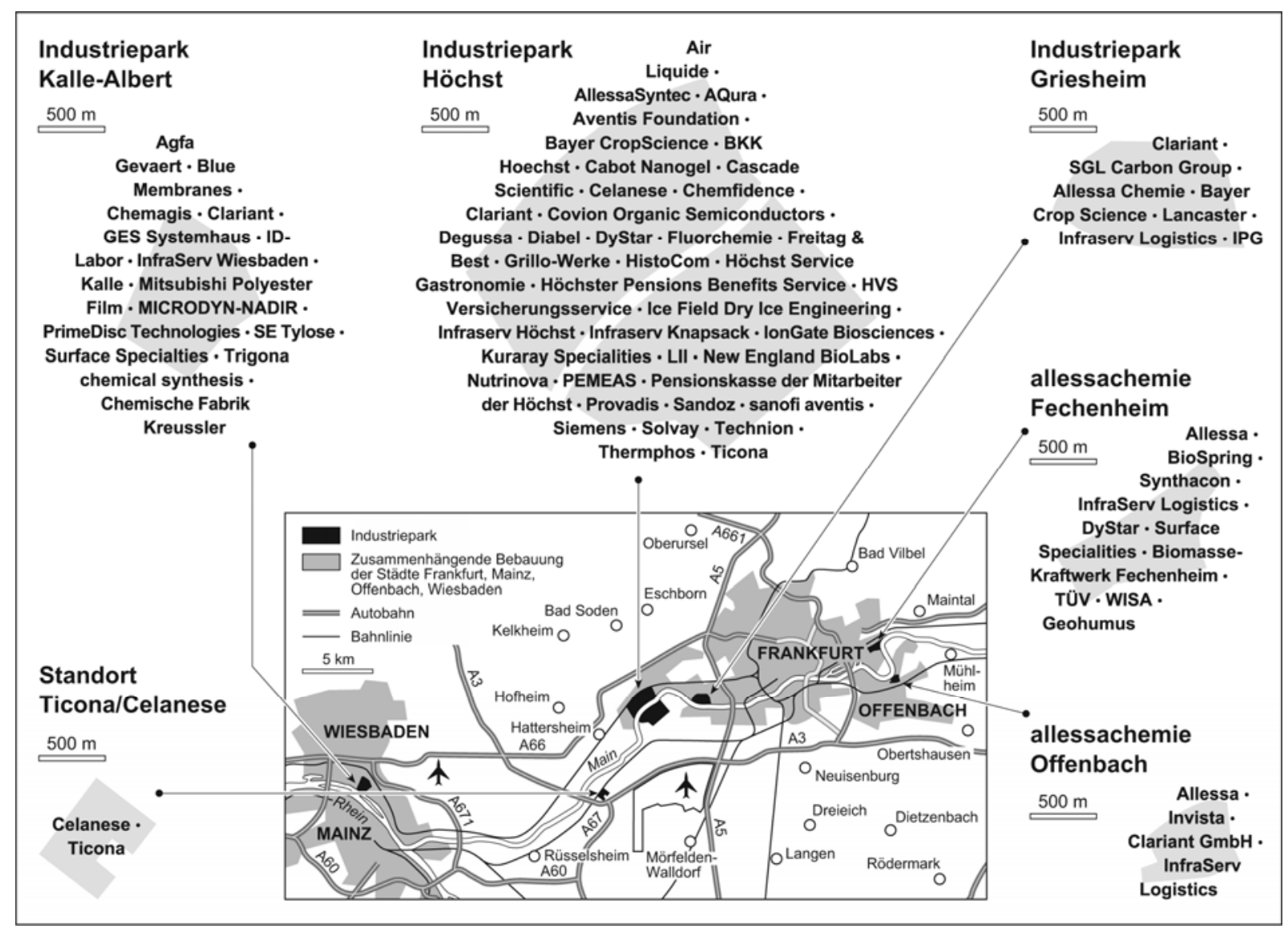


Figure 3. Structure of the former Rhône-Poulenc sites in Rhône-Alpes, 2006

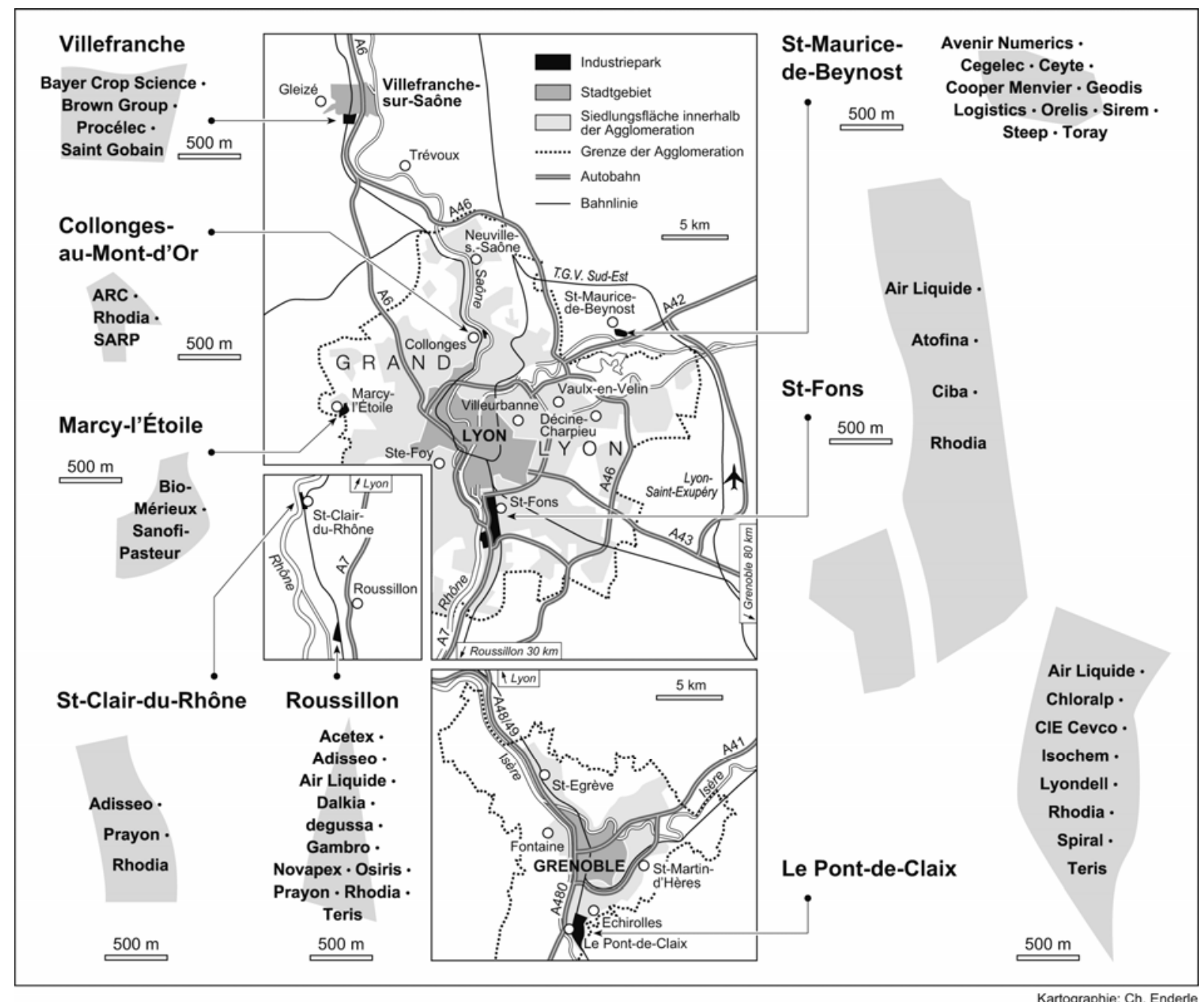

